\title{
Symulacyjne badanie wpływu nieliniowych charakterystyk podłoża na zachowanie toru wywołane przejazdami szybkich pojazdów szynowych
}

\begin{abstract}
$W$ artykule przedstawiono wyniki badań symulacyjnych przemieszczeń toru wywołanych przejazdem pociagu. Analizowano wplyw poszczególnych parametrów założonych wieloparametrowych nieliniowych charakterystyk sprężystości i tlumienia w podtożu na ugięcia toru.
\end{abstract}

\section{Uwagi wstępne}

Teoretyczne podstawy prowadzenia symulacyjnych badań ugięcia toru spowodowanych przejazdem szybkich pociagów zostały szczegółowo przedstawione w pracy [7]. W oparciu o wyprowadzone wzory został opracowany w pakiecie MATHEMATICA własny program $Z c \_b t-7 . n b$, który wraz $\mathrm{z}$ programem MVL.EXE umożliwia w szczególności prowadzenie symulacyjnych badań ugięć toru spowodowanych przejazdem pociagu. Badania te mają na celu, między innymi, określenie wpływu nieliniowości charakterystyki podłoża na ugięcie toru. Program $Z c_{-} b t-7 . n b$ służy do wyznaczania dodatkowych obciążeń obliczeniowych, które działając wraz z obciążeniami eksploatacyjnymi sprawiają, że analizowany układ liniowy zastępujący nieliniowy - zachowuje się podobnie jak układ rzeczywisty pod wpływem wyłącznie obciążeń eksploatacyjnych. Program MVL.EXE wyznacza ugięcia toru spowodowane zespołem ruchomych obciążeń eksploatacyjnych i dodatkowych obliczeniowych.

2. Wyniki badań symulacyjnych wpływu nieliniowości charakterystyki podłoża na ugięcie toru

W literaturze można spotkać wyniki poligonowych badań ugięć toru spowodowanych przejazdem pociągu. Rysunek 1. przedstawia wyniki badań eksperymentalnych uzyskanych na kolejach niemieckich DB [8]. Sa to ugięcia toru wywołane przejazdem dwóch wózków sassiednich wagonów pociagu ekspresowego ICE przejeżdżającego z prędkością $250 \mathrm{~km} / \mathrm{h}$, ze statycznym naciskiem wywoływanym przez jeden zestaw kołowy wynoszącym $140 \mathrm{kN}$. Rysunek ten przedstawia dwa wykresy ugięć wywołanych przejazdem sąsiednich wózków dwóch kolejnych wagonów. Górny wykres dotyczy pionowych ugięc zarejestrowanych czujnikiem związanym z szyną, a dolny czujnikiem związanym z podkładem.

Zaprezentowany przykład pozwala porównać wyniki badań eksperymentalnych z rezultatami otrzymanymi w wyniku badań symulacyjnych. Dlatego w badaniach symulacyjnych posłużono się modelem, który ma podobne parametry mechaniczne jak badany pociag w eksperymencie DB. Rysunek 2 przedstawia model przyjęty do badań symulacyjnych.

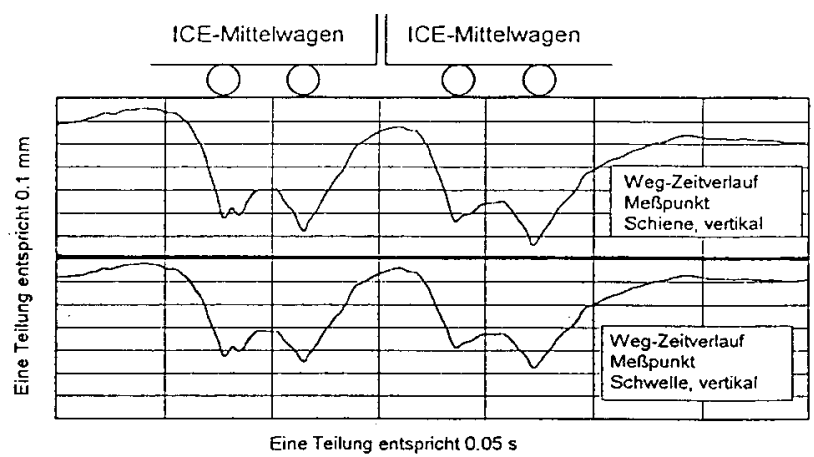

Rys 1. Wyniki eksperymentalnych badań ugięć toru [8]

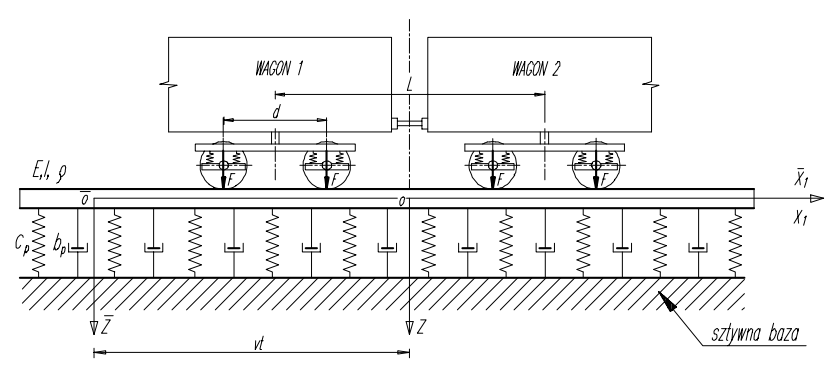

Rys 2. Model przyjęty do badań symulacyjnych

Część przyjętych parametrów jak prędkość jazdy, naciski zestawów kołowych ich rozmieszczenie, rodzaj szyn itp. jest znana. Pewne jednak fizyczne właściwości toru nie były jednoznacznie określone. Dotyczy to przykładowo parametru $c_{p}$ czyli stałej sprężystości składowej liniowej charakterystyki podłoża odniesionej do jednostki długości belki. Według szacunków popartych rozeznaniem literaturowym, w cytowanym eksperymencie DB, wartość $c_{p}$ wynosiła od 200 do $250 \mathrm{MN} / \mathrm{m}^{2}$. W prezentowanej analizie przyjęto wartość $c_{p}=230 \mathrm{MN} / \mathrm{m}^{2}$. Wartości liczbowe pozostałych parametrów analizowanego układu podano w pracy [7]. Przyjęte wartości parametrów pozwoliły przeliczyć współrzędne wymiarowe wykresu z eksperymentu DB przedstawionego na rysunku 1 (górna krzywa dotycząca ugięć mierzonych dla szyny) na stosowane w analizie współrzędne bezwymiarowe. 
Na rysunku 2 przedstawiony jest wykres ugięcia szyny z eksperymentu DB wykonany w przyjętych w badaniach symulacyjnych współrzędnych bezwymiarowych.

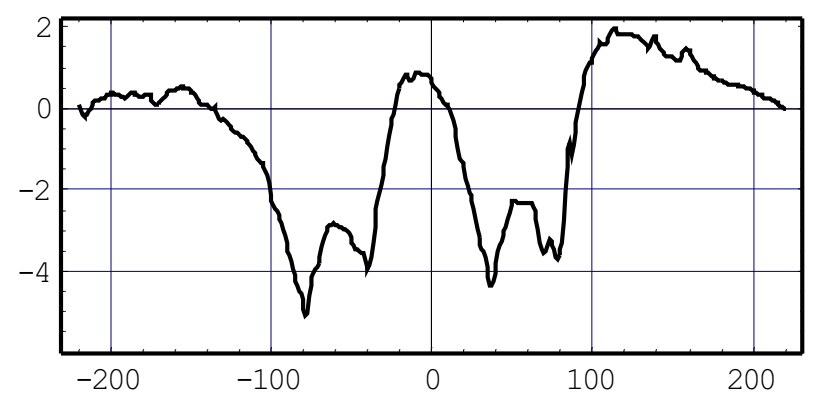

Rys. 3. Bezwymiarowe ugięcie szyn obliczone na podstawie eksperymentu DB.

Podczas badań symulacyjnych ugięć toru w pierwszej kolejności wyznaczono funkcję bezwymiarowego ugięcia toru spoczywającego na podłożu o liniowej charakterystyce. do modelu przedstawionego na rysunku 2. Rysunek 4 przedstawia wynik symulacji w przypadku obciazżenia $\mathrm{w}$ postaci układu czterech ruchomych sił skupionych (odpowiednio do badań na DB przyjęto naciski wywołane przez zestawy kołowe dwóch wózków sąsiednich wagonów, dla każdego zestawu po $140 \mathrm{kN}$ i zbliżone do układu rzeczywistego pozostałe parametry). We współrzędnych bezwymiarowych siły mają wartość 110 i rozmieszczone są w punktach $x$ o współrzędnych: - 80, -40, 40, 80.

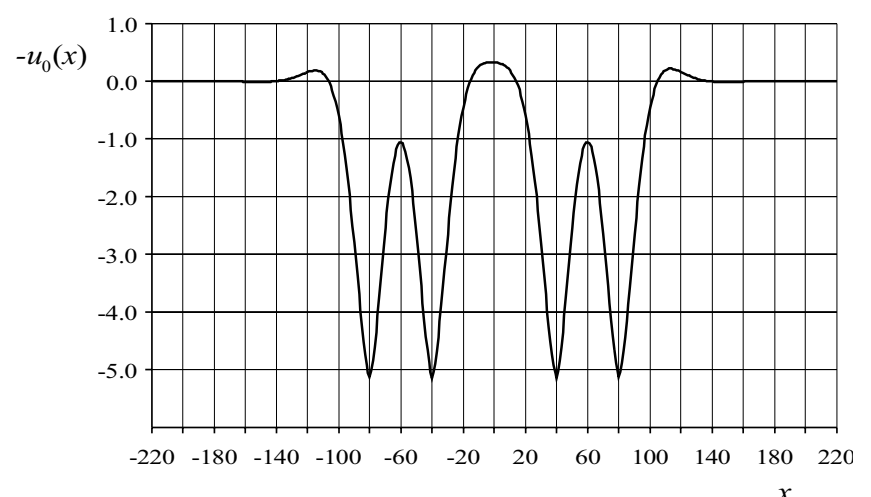

Rys. 4. Bezwymiarowe ugięcie toru do modelu wg rys 2 i liniowej charakterystyce podłoża

Porównując przedstawione na rysunkach 4 i 3 wykresy można zauważyć, że wyniki badań symulacyjnych układu liniowego nie odzwierciedlają w sposób zadowalający rezultatów badań eksperymentalnych gdyż odpowiedniejszym modelem układu dynamicznego pojazd szynowy - tor jest model uwzględniający nieliniowość.

Zgodnie z opisanym w pracy [7], proponowanym sposobem uwzględnienia wpływu nieliniowości na analizowany układ, zakładamy model nieliniowej, dwukrotnie załamanej charakterystyki sprężystości, pokazanej na rysunku 5 i charakterystykę tłumienia, przybliżającą tarcie suche, której model przedstawia rysunek 6.

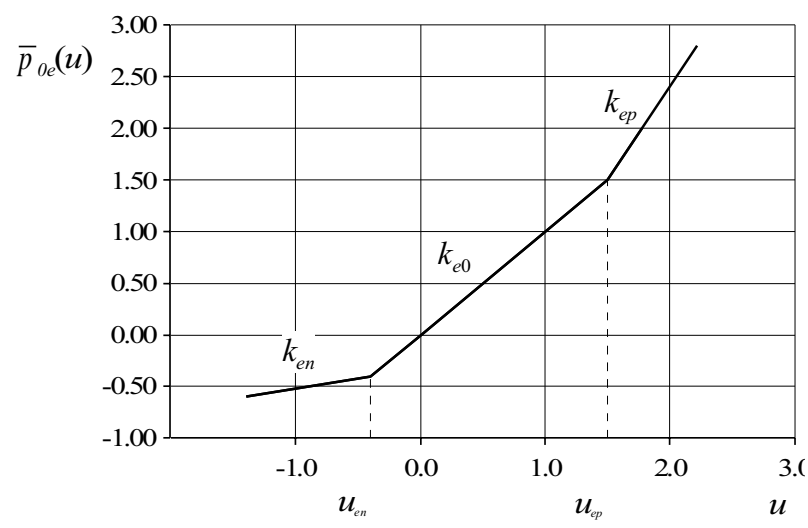

Rys.5. Bezwymiarowa nieliniowa charakterystyka sprężystości podłoża

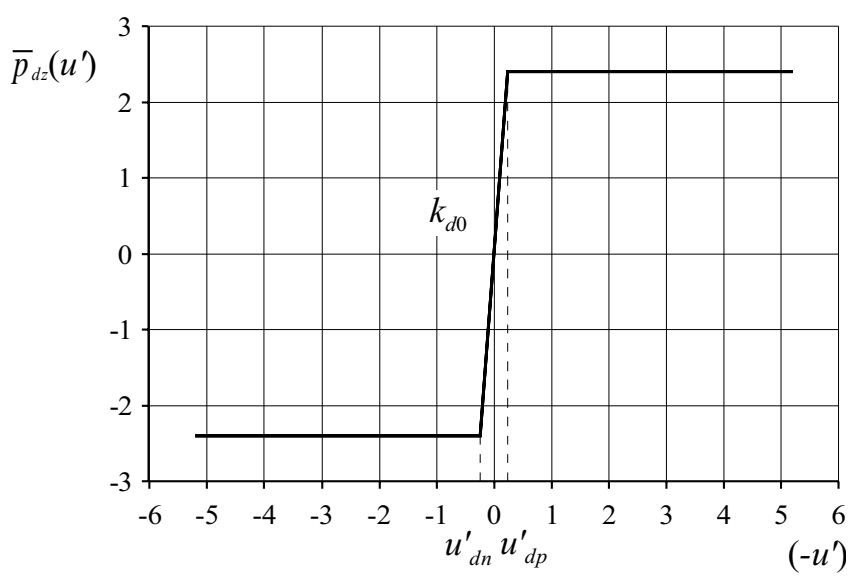

Rys.6. Bezwymiarowa nieliniowa charakterystyka tłumienia w podłożu

Przedstawioną na rysunku 5 przykładową nieliniową charakterystykę sprężystości określają, zgodnie z przyjętymi oznaczeniami, następujące parametry:

$u_{e n}=-0,4$ współrzędna punktu załamania charakterystyki przy ujemnym ugięciu,

$u_{e p}=1,5$ współrzędna punktu załamania charakterystyki przy dodatnim ugięciu,

$k_{e \mathrm{n}}=0,2$ współczynnik kierunkowy części charakterystyki przy $-\propto<u \leq u_{e n}$,

$k_{e p}=1,8$ współczynnik kierunkowy części charakterystyki przy $u_{e p} \leq u<+\propto$,

$k_{e 0}=1,0$ współczynnik kierunkowy środkowej części charakterystyki.

Przykładową nieliniową charakterystykę tłumienia, przedstawioną na rysunku 6 , definiują następujące parametry:

$u_{d n}^{\prime}=-0,24$ współrzędna początku poziomej części charakterystyki po stronie ujemnej,

$u_{d p}^{\prime}=0,24$ współrzędna początku poziomej części charakterystyki po stronie dodatniej,

$k_{d 0}=10,0$ współczynnik kierunkowy środkowej, przechodzącej przez punkt $(0,0)$, części charakterystyki. 
Mając tak przyjęte nieliniowości podłoża i parametry mechaniczne analizowanego układu, wyznaczono, opisaną w pracy [7] metodą badań symulacyjnych z wykorzystaniem własnych programów, Zc_bt-7.nb i $M V L . E X E$, ugięcie toru $u(x)$ spowodowane przejazdem dwóch wózków sąsiednich wagonów pociagu ekspresowego. Wynik tej symulacji przedstawiono na rysunku 7

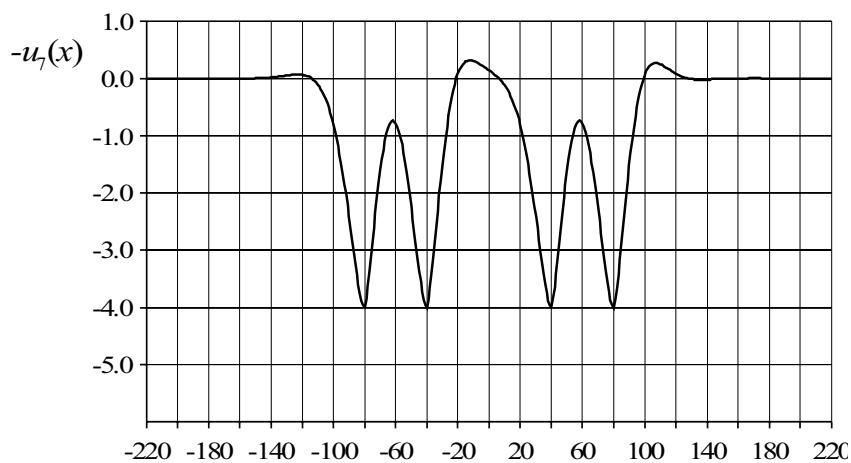

Rys. 7. Bezwymiarowe ugięcie toru do modelu wg rys $2 \stackrel{x}{\mathrm{i}}$ nieliniowej charakterystyce podłoża

Porównując wykresy przedstawione na rysunkach 5.3 i 5.11 widzimy, że uwzględnienie $w$ analizie nieliniowości podłoża spowodowało, w porównaniu z przypadkiem liniowym, zmniejszenie wartości ugięć maksymalnych oraz asymetrię uniesienia toru podobną do tej jaką zmierzono podczas eksperymentu DB przedstawionego na rysunku 5.2.

Zastosowana metoda badań symulacyjnych umożliwia zbadanie jaki jest wpływ poszczególnych parametrów założonych nieliniowości na zachowanie toru. Wyniki tych badań przedstawiono w następnych rozdziałach

\section{Badanie wpływu nieliniowej charakterystyki sprężystości podłoża na ugięcie toru}

W celu zbadania wpływu nieliniowej sprężystości podłoża na ugięcie toru zakładamy konkretne wartości parametrów nieliniowej charakterystyki sprężystości i liniową charakterystykę tłumienia podłoża a następnie zgodnie z przyjętą metodą symulacyjną, wyznaczymy funkcje ugięcia toru. Nieliniową sprężystość w przyjętym modelu charakteryzują parametry $u_{e n}, u_{e p}, k_{e n}$, $k_{e p}, k_{e 0} \ldots \mathrm{W}$ badaniach opisanych $\mathrm{w}$ tym rozdziale przyjmujemy, taką charakterystykę sprężystości, w której $u_{e n}=u_{e p}$ (brak liniowego, przechodzącego przez punkt 0,0 odcinka charakterystyki.

\subsection{Badanie wpływu załamania charakterystyki sprężystości po stronie ujemnej na ugięcie toru.}

W celu określenia wpływu załamania charakterystyki sprężystości po stronie ujemnej na ugięcie toru zakładamy nieliniową charakterystykę sprężystości załamaną jedynie po stronie ujemnej i liniową charakterystykę thumienia. Nieliniowość charakteryzuje w tym przypadku tylko jeden parametr $k_{e n}$ to jest współczynnik kierunkowy części charakterystyki sprężystości przy $-\propto<u \leq u_{e n}$, ponieważ punkt załamania tej charakterystyki ustalamy i przyjmujemy praktycznie w punkcie $(0,0)$. Wykresy przyjętych $\mathrm{w}$ tym eksperymencie charakterystyk sprężystości i thumienia przedstawia rysunek 8
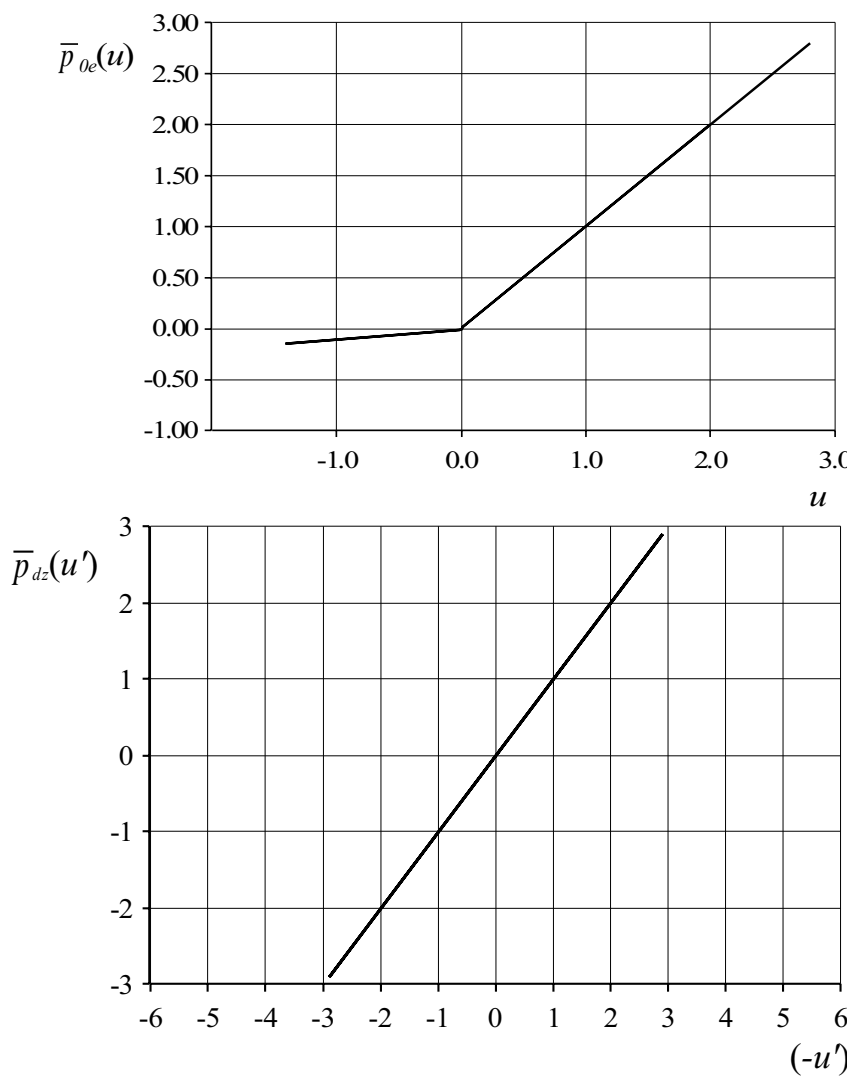

Rys.8. Bezwymiarowa charakterystyki nieliniowaj sprężystości i liniowego tłumienia w podłożu

Wynikowe ugięcie toru przy $k_{e n}=0,1$ przedstawia rysunek 9

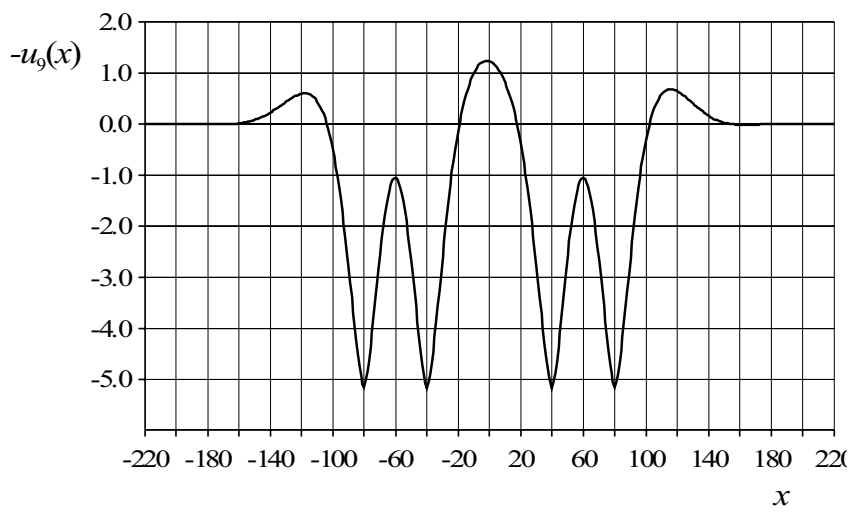

Rys. 9. Bezwymiarowe ugięcie toru przy $k_{e n}=0,1$

Przedstawiony przykład pokazuje, w jaki sposób na ugięcie toru wpływa załamanie charakterystyki sprężystości po stronie ujemnej. Przy przyjętych wartościach parametrów obserwuje się wzrost uniesienia toru w stosunku do przypadku liniowego. Wykonując 
kolejne symulacje przy różnych wartościach parametru $k_{e n}$ i nie zmieniając wartości pozostałych parametrów nieliniowości można stwierdzić następujące prawidłowości:

- przy $k_{e n}<1$ następuje wzrost uniesienia toru w stosunku do przypadku liniowego tym większy im mniejsza jest wartość $k_{e n}$,

- przy $k_{e n}>1$ następuje zmniejszenie uniesienia toru w stosunku do przypadku liniowego tym większe im większa jest wartość $k_{e n}$,

- istnieje pewna graniczna wartość $k_{e n}$, przy której zastosowana metoda symulacyjna nie daje rozwiązania.

\subsection{Badanie wpływu zalamania charakterystyki sprężystości po stronie dodatniej na ugięcie toru.}

W celu zbadania wpływu załamania charakterystyki sprężystości po stronie dodatniej na ugięcie toru przeprowadzono symulacje przy modelu nieliniowej sprężystości, którą charakteryzuje jedynie parametr $k_{e p}$ i przy liniowym thumieniu. Po wykonaniu szeregu badań symulacyjnych przy różnych wartościach parametru $k_{e p}$ zaobserwowano następujące prawidłowości:

- przy $k_{e p}<1$ następuje wzrost ugięcia i uniesienia toru w stosunku do przypadku liniowego tym większy im mniejsza jest wartość $k_{e p}$,

- przy $k_{e p}>1$ następuje zmniejszenie ugięcia i uniesienia toru $\mathrm{w}$ stosunku do przypadku liniowego tym większe im większa jest wartość $k_{e p}$,

- istnieje pewna graniczna wartość $k_{e p}$, przy której zastosowana metoda symulacyjna nie daje rozwiązania.

\section{Badanie wpływu nieliniowej charakterystyki tłumienia w podłożu na ugięcie toru}

Badania wykonano przy założeniu, że nieliniowa charakterystyka tłumienia w podłożu jest charakterystyką przybliżającą tarcie suche i ma ogólną postać przedstawioną na rysunku 6 . Badania symulacyjne prowadzono przy liniowej charakterystyce sprężystości, która nie miała wpływu na analizowane ugięcia. W wyniku licznie przeprowadzonych eksperymentów stwierdzono następujące prawidłowości.

$\mathrm{Z}$ porównania wykresów ugięcia toru w przypadku liniowym i przy nieliniowym tłumieniu, zbliżonym do tarcia suchego po stronie ujemnej wynika, że taki rodzaj tłumienia wpływa na zmniejszenie uniesienia toru, zwiększenie jego ugięcia oraz powoduje charakterystyczną asymetrię postaci tego ugięcia. W przypadku nieliniowego thumienia po stronie dodatniej obserwuje się wzrost bezwzględnej wartości uniesienia toru a także zmniejszenie ugięcia $\mathrm{w}$ stosunku do przypadku liniowego. Jednocześnie obserwuje się charakterystyczna asymetrie uniesienia toru podobną do tej jaka była stwierdzona podczas pomiarów kolei
DB (rysunek 3). Ponieważ wprowadzenie nieliniowego thumienia po stronie jedynie ujemnej i następnie jedynie dodatniej wywołuje przeciwstawne skutki można było wnioskować, że wprowadzenie symetrycznego nieliniowego thumienia jednocześnie przy dodatnich i ujemnych wartościach $u$ ' (charakterystyka thumienia jak na rysunku 6) spowoduje neutralizacje wpływu oddziaływania tych tłumień na wynikowe ugięcie toru i w efekcie rozwiązanie powinno być zbliżone do przypadku liniowego. Porównanie wykresów ugięcia w przypadku liniowym i w przypadku nieliniowego thumienia przybliżającego tarcie suche pokazało, że taka kompensacja nie zachodzi.

\section{Podsumowanie}

Przedstawione rezultaty przykładowych badań symulacyjnych wykazały przydatność proponowanej metody badań symulacyjnych wpływu różnych parametrów opisujących nieliniowość podłoża na zachowanie układu pojazd szynowy tor. Pokazały również jej ograniczenia polegające na tym że w pewnych zakresach wartości parametrów opisujących nieliniowość podłoża nie uzyskuje się rozwiązania. Prezentowane przykłady obejmowały badania układu pojazd szynowy tor przy jednakowej, stałej sprężystości składowej liniowej charakterystyki podłoża odniesionej do jednostki długości belki $c_{p}=230 \mathrm{MN} / \mathrm{m}^{2}$, i tej samej prędkości jazdy $v=250 \mathrm{~km} / \mathrm{h}$. Autor prowadził również badania symulacyjne mające na celu zbadanie wpływu sprężystości podłoża i prędkości jazdy na zachowanie układu pojazd szynowy tor. Przy założonych, ustalonych parametrach nieliniowości podłoża wykonywano badania przy różnych wartościach $c_{p}$ i $v$. Rezultaty tych eksperymentów były zgodne z przewidywaniami. Okazało się bowiem, że zmiana $c_{p}$ ma stosunkowo niewielki wpływ na kształt ugięcia toru natomiast ma wpływ na wartości maksymalne ugięć i uniesienia toru. Wzrostowi $c_{p}$ towarzyszy zmniejszenie maksymalnych wartości ugięcia i uniesienia toru. Nie jest to rezultat zaskakujący, gdyż można się było spodziewać, że im sztywniejsze podłoże tym ugięcia będa mniejsze. Prezentowana metoda pozwala jednak określić tę prawidłowość nie tylko jakościowo ale i ilościowo. Podobnie przedstawia się sytuacja w odniesieniu do prędkości przejazdu. Porównując wyniki uzyskane przy $350,250 \mathrm{i} 150 \mathrm{~km} / \mathrm{h}$ zauważamy, że zmiana prędkości przejazdu nie wpływa zasadniczo na postać ugięcia toru natomiast ma wpływ na wartości tych ugięć. Przy większych prędkościach jazdy maksymalne uniesienia i ugięcia toru są większe. Charakterystyczną asymetrię ugięcia toru, obserwowaną $\mathrm{w}$ badaniach poligonowych powoduje thumienie występujące w podłożu. 


\section{Literatura}

[1] Cichocki Z., Grzyb A.: Analiza drgań belki Timoshenki przy ruchomych obciażeniach ciagłych o dowolnym ksztatcie, Zbiór referatów IV Warsztatów Naukowych PTSK - Jelenia Góra 1997, „Symulacja w badaniach i rozwoju”, Warszawa 1998, s. 48-57.

[2] Cichocki Z.: Drgania toru kolejowego wywołane ruchem pojazdów, Zeszyty Naukowe Politechniki Ślqskiej, s. Transport, z. 31, 1998, s. 57-68.

[3] Cichocki Z., Grzyb A.: Nieliniowość podłoza przy modelowaniu uktadu dynamicznego pojazd szynowy-tor, Zeszyty Naukowe Politechniki Ślaskiej, s. Transport, z. 35, 1999, s. 11-21.

[4] Cichocki Z., Grzyb A.: Wplyw wybranych parametrów nieliniowego podłoża na zachowanie układu dynamicznego pojazd szynowy-tor, Zbiór referatów XIV Konferencji Naukowej Pojazdy Szynowe 2000, 1 Kraków-Arłamów 2000, T I, s. 33-44.
[5] Cichocki Z., Grzyb A.: Identyfikacja parametrów nieliniowego podłoża toru kolejowego, Zeszyty Naukowe Wydziału Mechanicznego Politechniki Koszalińskiej, $n r$ 28, 2001, s. 83-91.

[6] Cichocki Z., Grzyb A.: Wptyw wybranych parametrów podłoża toru na jego ugięcia dynamiczne, Zbiór referatów XVII Konferencji Naukowej Pojazdy Szynowe, Kazimierz Dolny, 13 - 15 września 2006, s. $291-300$.

[7] Cichocki Z.: Modelowanie uktadu pojazd szynowy-tor przy duzych prędkościach jazdy, praca doktorska, Politechnika Krakowska, Kraków 2008.

[8] Hochbruck H., Knothe K., Meinke P.: Elastische Zwischenlagen im Gleis lösen Schwingungsprobleme, „Systemdynamik der Eisenbahn“, Hennigsdorf 13, 14 X 1994, s. 87-95. 